\title{
Erratum to epidermal inclusion cyst in the thyroid gland
}

\section{Editorial Office}

Stem Cell Investigation

Correspondence to: Editorial Office. Stem Cell Investigation. Email: editor@sci-online.org.

Received: 16 July 2021; Accepted: 12 August 2021; Published: 17 August 2021.

doi: $10.21037 /$ sci-2021-01

View this article at: https://dx.doi.org/10.21037/sci-2021-01

Erratum to: Stem Cell Investig 2020;7:18

The article titled "Epidermal inclusion cyst in the thyroid gland" (1) was published with two errors. The author name "Salini Kunar" was spelled wrong. The correct spelling in the author list should be "Salini Kumar". Besides, the "Cite this article as" section should be corrected as below:

Cite this article as: Palacio MN, Gonzalez-Mosquera L, Rosenthal D, Kumar S, Tao Q, Gebre W, Liao H. Epidermal inclusion cyst in the thyroid gland. Stem Cell Investig 2020.

Click here to view the updated version of the article.

Open Access Statement: This is an Open Access article distributed in accordance with the Creative Commons AttributionNonCommercial-NoDerivs 4.0 International License (CC BY-NC-ND 4.0), which permits the non-commercial replication and distribution of the article with the strict proviso that no changes or edits are made and the original work is properly cited (including links to both the formal publication through the relevant DOI and the license). See: https://creativecommons.org/licenses/by-nc$\mathrm{nd} / 4.0 /$.

\section{References}

1. Palacio MN, Gonzalez-Mosquera L, Rosenthal D, et al. Epidermal inclusion cyst in the thyroid gland. Stem Cell Investig 2020;7:18.

doi: $10.21037 /$ sci-2021-01

Cite this article as: Editorial Office. Erratum to epidermal inclusion cyst in the thyroid gland. Stem Cell Investig 2021;8:17. 